\title{
The Role of Inorganic Metal Salts in Wastewater Clarification
}

L.N. Ukiwe ${ }^{a}$, I.C. Iwu ${ }^{b}$, Chijioke-Okere $M^{c}$

${ }^{a, b, c}$ Department of Chemistry, Federal University of Technology, Owerri, Nigeria

Corresponding author: luggil2002@yahoo.com

\section{ABSTRACT}

An investigation into the ability of four inorganic coagulants namely; alum $\left(\mathrm{Al}_{2}\left(\mathrm{SO}_{4}\right)_{3} .18 \mathrm{H}_{2} \mathrm{O}\right)$, ammonium aluminum sulphate $\left(\mathrm{NH}_{4} \mathrm{Al}\left(\mathrm{SO}_{4}\right)_{2} .12 \mathrm{H}_{2} \mathrm{O}\right)$, ferrous sulphate $\left(\mathrm{FeSO}_{4}\right)$ and ammonium ferrous sulphate $\left.\left(\mathrm{NH}_{4}\right)_{2} \mathrm{Fe}\left(\mathrm{SO}_{4}\right)_{2} .6 \mathrm{H}_{2} \mathrm{O}\right)$ in clarifying wastewater was examined. Results obtained from conventional standard 'jar-test' experiments indicated that alum was the most effective coagulant since it reduced turbidity of the wastewater to 0.64 NTU at a contact time of 300 min. Ferrous sulphate was the least effective coagulant, reducing turbidity of the wastewater to 3.45 NTU only at 240 min contact time, but when the contact time of the experiment was increased from 240 to 300 min, re-coloration of the solution was observed indicating re-stabilization of suspended particles. These findings tend to support the claim that alum is a choice coagulant for wastewater clarification.

\section{Indexing terms/Keywords}

Coloration, concentration, environment, ferric sulphate, redox reaction, solution, turbidity

\section{Academic Discipline And Sub-Disciplines}

Environmental chemistry

\section{SUBJECT CLASSIFICATION}

Chemistry

\section{TYPE (METHOD/APPROACH)}

Experimental study

\section{Council for Innovative Research}

Peer Review Research Publishing System

Journal: Journal of Advances in Chemistry

Vol 4, No.1

editor@cirworld.com

www.cirworld.com, member.cirworld.com 


\subsection{INTRODUCTION}

The need for clean quality water is increasing all the time; hence the aesthetic quality of water has become an essential priority for water treatment plants. Coloration in water is an indication of the presence of organic substances, including humic and fulvic acids, some bacteria forms, and natural metallic ions (1). All waters (surface and ground waters) contain dissolved and suspended particles. The dissolved particles impact color to the water, while suspended matter vary considerably in composition charge, particle size, shape and density. Smaller particles are kept in suspension (stabilized) by action of physical forces resulting from the surface charge present on the particles. Negative charges predominate in most suspended solids This is the sole reason why suspended particles remain suspended (colloidal/nonsettleable) rather than clump together and settle out of the water.

Coagulation/flocculation is a process that removes colloid and nonsettleable solids from water and wastewater. Since colloids have a negative charge, it is expected that a positively charged coagulant will neutralize the negative charge during the coagulation process, while in the flocculation process, particles are drawn together by Van der Waals forces forming flocs that settle out of the water due to gravity. The proper type and concentration of coagulant are essential to the coagulation process. The condition of the water treatment plant is an important factor to consider when selecting the type of coagulant to be used. However, the coagulant's concentration depends on the water conditions.

Alum $\left(\mathrm{Al}_{2}\left(\mathrm{SO}_{4}\right)_{3} \cdot 18 \mathrm{H}_{2} \mathrm{O}\right)$ has been demonstrated to have relatively high coagulating power since its trivalent state is capable of destabilizing negative charges of colloids present in water effectively (2). Evidence has been accumulating to suggest that by adding $150 \mathrm{~mL}^{-1}$ of alum at a contact time of $20 \mathrm{~min}$, clarification of wastewater was improved to about $90 \%$ (3). El-Gohary (4) compared the effectiveness of alum, ferric chloride $\left(\mathrm{FeCl}_{3}\right)$, and ferrous sulphate $\left.(\mathrm{FeSO})_{4}\right)$ in treating wastewater and concluded that alum produced higher natural organic matter removal compared to $\mathrm{FeCl}_{3}$ and $\mathrm{FeSO}_{4}$. Related studies by Verma et al. (5) and Kushwaha et al. (6) had documented evidence showing that $\mathrm{FeCl}_{3}$ and $\mathrm{FeSO}_{4}$ were also effective in clarifying petrochemical and dairy wastewaters. Inorganic metal salts have been noted as established coagulants in water and wastewater treatment. Several studies (7), (8), (9), and (10) have observed that $\mathrm{FeCl}_{3}(7)$, alum (8),(9) and combination of $\mathrm{Al} / \mathrm{Fe}$ (III) salts (10) are effective in removing dissolved organic matter, humic substances, and color-causing natural organic materials from wastewaters. In further studies, Kim and Kang (11) revealed that $\mathrm{FeCl}_{3}$ was effective as a coagulant in studying coagulation mechanism and flocculation dynamics in wastewater treatment. The study observed that measurement of flocculation dynamics by assessing the rate of change in total particle number concentration of the coagulant provided reliable indication on complete charge neutralization under adsorption/destabilization conditions. Kim and Kang (11) further proposed that Fe (III) salts are receiving attention as alternative coagulants to alum for wastewater treatment due to several reasons among which is the concern of aluminum build-up in treated water as well as better Fe (III) coagulation efficiency at low water temperature and more efficient removal of organic matter by Fe (III) salts than alum. Changes in Fe (II) and Fe (III) salts contents in test solution as a result of coagulation when turbidity level was investigated revealed that the lowest concentration of total Fe levels was observed following application of optimal coagulant doses, but high coagulant doses led to increase in total Fe levels in all test solutions, indicating that increase in total Fe content might have been due to redox reactions (12). Samrani et al. (13) reported extensively on the use of $\mathrm{FeCl}_{3}$ and polyaluminum chloride (PAC) as chemical coagulants in removal of turbidity in sewage sludge. The study noted that an efficient turbidity removal was achieved with both coagulants, though, using the aluminum based coagulant at lower optimum dosage, higher re-stabilization concentration of the suspension was observed.

Attempts have been made to examine the effectiveness of $\mathrm{FeCl}_{3}$ as coagulant in treating beverage industrial wastewater. According to Amuda and Amoo (14), percentage removal of natural organic matter was $91 \%$, achieved by addition of 300 $\mathrm{mg} / \mathrm{L}$ of $\mathrm{FeCl}_{3}$. In a separate study, (11) observed that $\mathrm{FeCl}_{3}$ was more efficient than PAC in treating petrochemical wastewater. Based on results obtained of 'jar test', the authors concluded that varying the $\mathrm{pH}$ of the test solution did not significantly affect color removal of the wastewater. In addition to these recognized studies, a growing body of literature have been reporting on the effectiveness of alum (16),(17) and other forms of chemical coagulants such as calcium oxide (18), combination of alum and $\mathrm{FeCl}_{3}$ (19), silicates (20) as well as electrocoagulation (21) in wastewater treatment.

The aim of the present study was to evaluate and compare the effectiveness of four inorganic coagulants namely: alum $\left(\mathrm{Al}_{2}\left(\mathrm{SO}_{4}\right)_{3} .18 \mathrm{H}_{2} \mathrm{O}\right)$, ammonium aluminum sulphate $\left(\mathrm{NH}_{4} \mathrm{Al}\left(\mathrm{SO}_{4}\right)_{2} .12 \mathrm{H}_{2} \mathrm{O}\right)$, ferrous sulphate $(\mathrm{FeSO})_{4}$ and ammonium ferrous sulphate $\left.\left(\mathrm{NH}_{4}\right)_{2} \mathrm{Fe}\left(\mathrm{SO}_{4}\right)_{2} \cdot 6 \mathrm{H}_{2} \mathrm{O}\right)$ in turbidity removal in storm-water runoff.

\subsection{Materials and Methods}

\subsection{Sample preparation}

The wastewater used in this experiment was prepared by mixing $1 \mathrm{~kg}$ of muddy soil with $2 \mathrm{~L}$ of tap water. This was done to simulate a wastewater type similar to storm-water runoff. The mixture was stirred thoroughly at $65 \mathrm{rpm}$ using a centrifuge (MC5415C, Akson Scientific Instrument, Akwa, Nigeria) for $10 \mathrm{~min}$ and allowed to stand for $1 \mathrm{hr}$. Debris and particles were removed by screening and filtration through a $10 \mathrm{~mm}$ mesh sieve and the supernatant decanted into a $5 \mathrm{~L}$ beaker. The pH of the mixture was adjusted to 8.0 using a pH meter (PHS 25, Shanghai. Xinrui Instrument, China) by adding $\mathrm{NaOH} / \mathrm{HCl}$ as appropriate. This mixture was used as the stock solution.

\subsection{Coagulation/flocculation experiment}

The experiments were all done by applying conventional 'jar test' method. All the experiments were carried out at room temperature. One litre $(1 \mathrm{~L})$ of the stock solution was measured into a $2 \mathrm{~L}$ beaker and $10 \mathrm{~g}$ of alum was weighed and added to the stock solution in the $2 \mathrm{~L}$ beaker. The mixture was stirred repeatedly with a centrifuge at $150 \mathrm{rpm}$ for 5 min (quick 
agitation phase for hydrolysis) until the coagulant dissolved completely. The mixture was left to stand for 30 min and stirred again repeatedly for $10 \mathrm{~min}$ at $20 \mathrm{rpm}$ (slow agitation phase for floc growth) and allow to settle for $30 \mathrm{~min}$. After settling, about $10 \mathrm{ml}$ of the supernatant was siphoned with a syringe from about $25 \mathrm{~mm}$ below the surface of the mixture and residual turbidity of the mixture determined using a turbidimeter (WGZ-IB, Shanghai Xinrui Instruments, China). Three repeations were performed and the mean turbidity value obtained. This procedure was repeated every $30 \mathrm{~min}$ for $5 \mathrm{hr}$. However, the entire procedure was repeated using $\mathrm{NH}_{4} \mathrm{Al}\left(\mathrm{SO}_{4}\right)_{2} .12 \mathrm{H}_{2} \mathrm{O}, \mathrm{FeSO}_{4}$ and $\left(\mathrm{NH}_{4}\right)_{2} \mathrm{Fe}\left(\mathrm{SO}_{4}\right)_{2} .6 \mathrm{H}_{2} \mathrm{O}$ salts, respectively.

\subsection{Results}

Table 1: Turbidity values of various coagulants at different contact times

\begin{tabular}{|c|c|c|c|c|}
\hline $\begin{array}{l}\text { Contact } \\
\text { time } \\
\qquad(\min )\end{array}$ & $\begin{array}{l}\mathrm{Al}_{2}\left(\mathrm{SO}_{4}\right)_{3} \cdot 18 \mathrm{H}_{2} \mathrm{O} \\
\text { Mean }(\mathrm{NTU}) \pm \mathrm{SD}\end{array}$ & $\begin{array}{l}\mathrm{NH}_{4} \mathrm{Al}\left(\mathrm{SO}_{4}\right)_{2} \cdot 12 \mathrm{H}_{2} \mathrm{O} \\
\text { Mean }(\mathrm{NTU}) \pm \mathrm{SD}\end{array}$ & $\begin{array}{c}\mathrm{FeSO}_{4} \\
\text { Mean(NTU) } \pm \mathrm{SD}\end{array}$ & $\begin{array}{l}\left(\mathrm{NH}_{4}\right)_{2} \mathrm{Fe}\left(\mathrm{SO}_{4}\right)_{2} \cdot 6 \mathrm{H}_{2} \mathrm{O} \\
\text { Mean(NTU) } \pm \text { SD }\end{array}$ \\
\hline 30 & $20.00 \pm 0.1$ & $19.98 \pm 1.2$ & $18.92 \pm 1.0$ & $20.00 \pm 0.1$ \\
\hline 60 & $18.05 \pm 0.1$ & $15.72 \pm 0.1$ & $18.14 \pm 1.1$ & $18.95 \pm 0.2$ \\
\hline 90 & $9.66 \pm 0.0$ & $13.00 \pm 1.0$ & $15.44 \pm 0.1$ & $15.74 \pm 1.0$ \\
\hline 120 & $9.19 \pm 0.1$ & $10.17 \pm 0.1$ & $8.53 \pm 0.1$ & $13.20 \pm 0.1$ \\
\hline 150 & $7.22 \pm 0.1$ & $8.32 \pm 0.1$ & $6.23 \pm 0.2$ & $8.75 \pm 0.1$ \\
\hline 180 & $5.33 \pm 0.1$ & $6.56 \pm 0.1$ & $4.26 \pm 0.1$ & $4.28 \pm 1.0$ \\
\hline 210 & $4.20 \pm 0.2$ & $4.45 \pm 0.1$ & $3.31 \pm 0.2$ & $3.98 \pm 0.1$ \\
\hline 240 & $3.68 \pm 0.1$ & $3.43 \pm 0.1$ & $7.46 \pm 0.1$ & $3.51 \pm 0.1$ \\
\hline 270 & $0.83 \pm 0.0$ & $2.93 \pm 0.1$ & $10.15 \pm 0.1$ & $3.33 \pm 0.1$ \\
\hline 300 & $0.64 \pm 0.0$ & $1.04 \pm 0.1$ & $15.20 \pm 0.1$ & $2.98 \pm 0.1$ \\
\hline
\end{tabular}

\subsection{Discussion}

Coagulation/flocculation are two processes where by an addition of a positively charged ion of a metal salt results in particle destabilization, charge neutralization and agglomeration of colloids into visible floc masses to clarify wastewater. Wastewater clarification is a funtion of the extent of turbidity in the solution. Turbidity represent suspended particulate matter in solution. Two distinct fractions of suspended particulate matter exist in solution: a coarse fraction ( $1 \mathrm{~mm}$ to $1 \mu \mathrm{m})$ and a colloid fraction $\left(1 \mu \mathrm{m}\right.$ to $\left.10{ }^{\circ} \mathrm{A}\right)(22)$. Conventional coagulation/flocculation treatment removes the coarse fraction, however, the colloid fraction can only be removed effectively by lowering the zeta potential between the floc and the colloids. The floc formed during the coagulation/flocculation process is of the same charge as that of the particles before treatment, hence, a mutual repulsion develops between the floc particles and the colloids (22). These repelling forces prevent the colloid from making contact with the floc and it is only by applying a proper dosage of an inorganic coagulant would the zeta potential be reduced, hence, floc aggregation of particles (23).

Zeta potential is the potential difference between inter-phase substances. A knowledge of zeta potential is important to predict and control the stability of colloidal suspension (turbidity). The greater the zeta potential, the more likely the suspension will remain in a stable form. Nevertheless, conversion of stable dispersion to unstable state is achieved through destabilization, a process made possible by coagulation/flocculation (24).

In Table 1, turbidity values of $\mathrm{Al}_{2}\left(\mathrm{SO}_{4}\right)_{3} .18 \mathrm{H}_{2} \mathrm{O}, \mathrm{NH}_{4} \mathrm{Al}\left(\mathrm{SO}_{4}\right)_{2} .12 \mathrm{H}_{2} \mathrm{O}, \mathrm{FeSO}_{4}$ and $\left(\mathrm{NH}_{4}\right)_{2} \mathrm{Fe}\left(\mathrm{SO}_{4}\right)_{2} \cdot 6 \mathrm{H}_{2} \mathrm{O}$ coagulants are shown. It was observed that using $\mathrm{Al}_{2}\left(\mathrm{SO}_{4}\right)_{3} \cdot 18 \mathrm{H}_{2} \mathrm{O}$ coagulant, a decrease in turbidity value was noted as the contact was increased from 30 to $300 \mathrm{~min}$ (5hr). The best clarification of the wastewater was achieved at 300 min with a turbidity value of $0.64 \mathrm{NTU}$ for $\mathrm{Al}_{2}\left(\mathrm{SO}_{4}\right)_{3} .18 \mathrm{H}_{2} \mathrm{O}$ coagulant. Equally at $300 \mathrm{~min}, 1.04$ and $2.98 \mathrm{NTU}$ were obtained as turbidity values for the best clarification of the wastewater using $\mathrm{NH}_{4} \mathrm{Al}\left(\mathrm{SO}_{4}\right)_{2} .12 \mathrm{H}_{2} \mathrm{O}$ and $\left(\mathrm{NH}_{4}\right)_{2} \mathrm{Fe}\left(\mathrm{SO}_{4}\right)_{2} \cdot 6 \mathrm{H}_{2} \mathrm{O}$ coagulants, respectively. $\mathrm{A}$ general decrease in trend of turbidity value was noted for the above mentioned coagulants $\left(\mathrm{Al}_{2}\left(\mathrm{SO}_{4}\right)_{3} .18 \mathrm{H}_{2} \mathrm{O}\right.$, $\mathrm{NH}_{4} \mathrm{Al}\left(\mathrm{SO}_{4}\right)_{2} .12 \mathrm{H}_{2} \mathrm{O}$, and $\left.\left(\mathrm{NH}_{4}\right)_{2} \mathrm{Fe}\left(\mathrm{SO}_{4}\right)_{2} .6 \mathrm{H}_{2} \mathrm{O}\right)$ as the contact time increased from 30 to 300 min. However, using FeSO as coagulant, the best turbidity decrease (3.31 NTU) was observed at $210 \mathrm{~min}$, but as the contact time was increased from 210 to $300 \mathrm{~min}$ an increase in turbidity value was observed indicating re-coloration of the solution.

Libecki and Dziejowski (25) in an earlier study had suggested that the presence of dissolved organic substances in the form of organic ferric complexes could be responsible for increase in solution coloring during application of $\mathrm{FeSO}_{4}$ as coagulant for clarifying wastewater. The authors are of the opinion that Fe (II) ions under-go redox reactions resulting in the production of $\mathrm{Fe}$ (III) ions which react with dissolved organic matter to form the organic ferric complex. This phenomenon impacts color to solutions. Furthermore, Chen et al. (26) had previously proposed that redox reactions take 
place in standard coagulation test environment and the reaction is affected by several factors among which are; the type of organic substances present in the solution, the concentration of the organic substances in the solution, light intensity, oxygen content, and the time of solution mixing condition. The present study agree with the opinion shared by the above mentioned authors and concluded that the recoloration of the solution during the application of $\mathrm{FeSO}_{4}$ as coagulant was as a result of organic ferric complex formed by the oxidation of $\mathrm{Fe}$ (II) to Fe (III) ions in the test solution after the test solution has been mixed for some amount of time. In addition to the above, recoloration of the test solution in the present study may have resulted from restabilization of suspended particles due to increase in the zeta potential between the floc and the colloids. As previously mentioned, the zeta potential of the oxidized Fe (III) ions in solution may have led to charge reversal, where the particle charge of the repulsive forces remain high thereby restabilizing the suspension given rise to recoloration. While noting that $\mathrm{Al}_{2}\left(\mathrm{SO}_{4}\right)_{3} \cdot 18 \mathrm{H}_{2} \mathrm{O}$ was the best coagulant used in clarifying storm-water runoff among the four coagulants examined, the present study advocates for more research on the application of Fe (II) and Fe (III) salts in wastewater treatment to ascertain a full explaination of the effect recoloration and restabilization of suspended particles have on turbidity removal, and which of these salts is most effective in wastewater clarification.

\section{REFERENCES}

1. Crittenden, J., Montgomery W. H. Water treatment principles and design. ( $1^{\text {st }}$ Edn.). New York, USA: Wiley Publishers. (2005). pp 80-92.

2. Casey, T.J. Unit treatment processes in water and wastewater engineering. $\left(1^{\text {st }}\right.$ Edn.). New York, USA: Wiley Publishers. (1997). pp 215-232.

3. Ukiwe, L.N., \& Alinnor, J.I. Assessment of polyacrylamide and aluminum sulphate coagulants in turbidity removal in wastewater. Terrestrial and Aquatic Environmental Toxicology, (2012). 6: 132-135.

4. El-Gohary, F., Tawfik, A., \& Mahmoud, U. Comparative study between chemical coagulation/precipitation versus coagulation/dissolved air flotation for pre-treatment of personal care products wastewaters. Desalination, (2010). 252: 106-112.

5. Verma, S., Prasad, B., \& Mishra, I.M. Pretreatment of petrochemical wastewater by coagulation and flocculation and the sludge characteristics. Journal of Hazardous Materials, (2010). 178: 1055-1064.

6. Kushwaha, J.P., Srivastava, V.C., \& Mall, I.D. Treatment of diary wastewater by inorganic coagulants: Parametric and disposal studies. Water Research, (2010). 44: 5867-5874.

7. Amirtharajah, A., Denneth, K.E., \& Studstill, A.A. Ferric chloride coagulation for removal of dissolved organic matter and trihalomethane precursors. Water Science and Technology, (1993). 27: 113-121.

8. Dempsey, B.A., Ganho, R.M., \& O'Melia, C.R. The coagulation of humic substances by means of aluminum salts. Journal of American Water Works Association, (1984). 76: 141-149.

9. He, Z.J., Li, S., \& Zhang, L. Treatment of industrial wastewater and sludge dehydration with inorganic high molecular weight coagulants. Shanghai Environment Science, (1987). 6: 32-34.

10. Jiang, J.Q., \& Graham, N.J.D. Enhanced coagulation using Al/Fe (III) coagulants: Effect of coagulant chemistry on the removal of color-causing NOM. Environmental Technology, (1996). 17: 937-950.

11. Kim, J., \& Kang, L. Investigation of coagulation mechanism with Fe (III) salt using jar tests and flocculation dynamics. Environmental Engineering Research, (1998). 3: 11-19.

12. Libecki, B., \& Dziejowski, J. Changes in iron (II) and iron (III) content in a solution of humic acids during coagulation by means of monomeric iron (III) salts. Polish Journal of Environmental Studies, (2010). 19: 1089-1093.

13. Samrani, A.G., Lartige, B.S., \& Villiéras, F. Chemical coagulation of combined sewer overflow: Heavy metal removal and treatment optimization. Water Research, (2008). 42: 951-960.

14. Amuda, O.S., \& Amoo, I.A. Coagulation/flocculation process and sludge conditioning in beverage industrial wastewater treatment. Journal of Hazardous Materials, (2006). 141: 778-783.

15. Farajnezhad, H., \& Gharbani, P. Coagulation treatment of wastewater in petroleum industry using polyaluminum chloride and ferric chloride. International Journal of Research and Reviews in Applied Sciences, (2012). 13: $306-310$.

16. Amokrane, A., Comel, C., \& Veron, J. Landfill leachates pre-treatment by coagulation-flocculation. Water Research, (1997). 31: 2775-2782.

17. Korbutowicz, M.K. Effect of Al coagulant type on natural organic matter removal efficiency in coagulation/ultrafiltration process. Desalination, (2005). 185: 327-333.

18. Vaccari, M., Gialdini, F., \& Collivignarelli, C. Study of the reuse of treated wastewater on waste container washing vehicles. Waste Management, (2012). 33: 262-267.

19. Xie, J., Wang, D., Leeuwen, J., Zhao, Y., Xing, L., \& Chow, C.W.K. pH modelling for maximun dissolved organic matter removal by enhanced coagulation. Journal of Environmental Sciences, (2012). 24: 276-283. 
20. Wang, D., \& Tang, H. Modified inorganic polymer flocculant-PFSi: Its preparation, characterization and coagulation behaviour. Water Research, (2001). 35: 3418-3428.

21. Butler, E., Hung, Y.T., Yeh, R.Y., \& Ahmad, M.S. Electrocoagulation in wastewater treatment. Water, (2011). 3: 495525.

22. Hughes, M.A. Coagulation and flocculation, Part 1 in solid-liquid separation. ( $3^{\text {rd }}$ Edn.). L. Svarosky (ed). Belfast, UK: Butterworth \& Co. Publishers. (1990). p 74.

23. Gregory, J. Stability and flocculation of suspension in proc. Solid-liquid dispersions. (1 ${ }^{\text {st }}$ Edn.). P. Shamlou (ed). Belfast, UK: Butterworth-Heinemann Ltd. (1993). p 3.

24. Tripathy, T., \& De-Ranjan, B. Flocculation: A new way to treat the wastewater. Journal of Physical Sciences, (2006). 10: 93-127.

25. Libecki, B., \& Dziejowski, J. Interactions of aluminum and iron (III) salts with humic acids in a model alkaline solution. Polish Journal of Natural Science, (2008). 23: 681-686.

26. Chen, Y., Zaiiraa, O., \& Bouchy, M. Inhibition of adsorption and photocatalytic degradation of an organic contaminant in an aqueous suspension of $\mathrm{TiO}_{2}$ by inorganic ions. Journal of Photochemistry and Photobiology, (1997). A108: 3745.

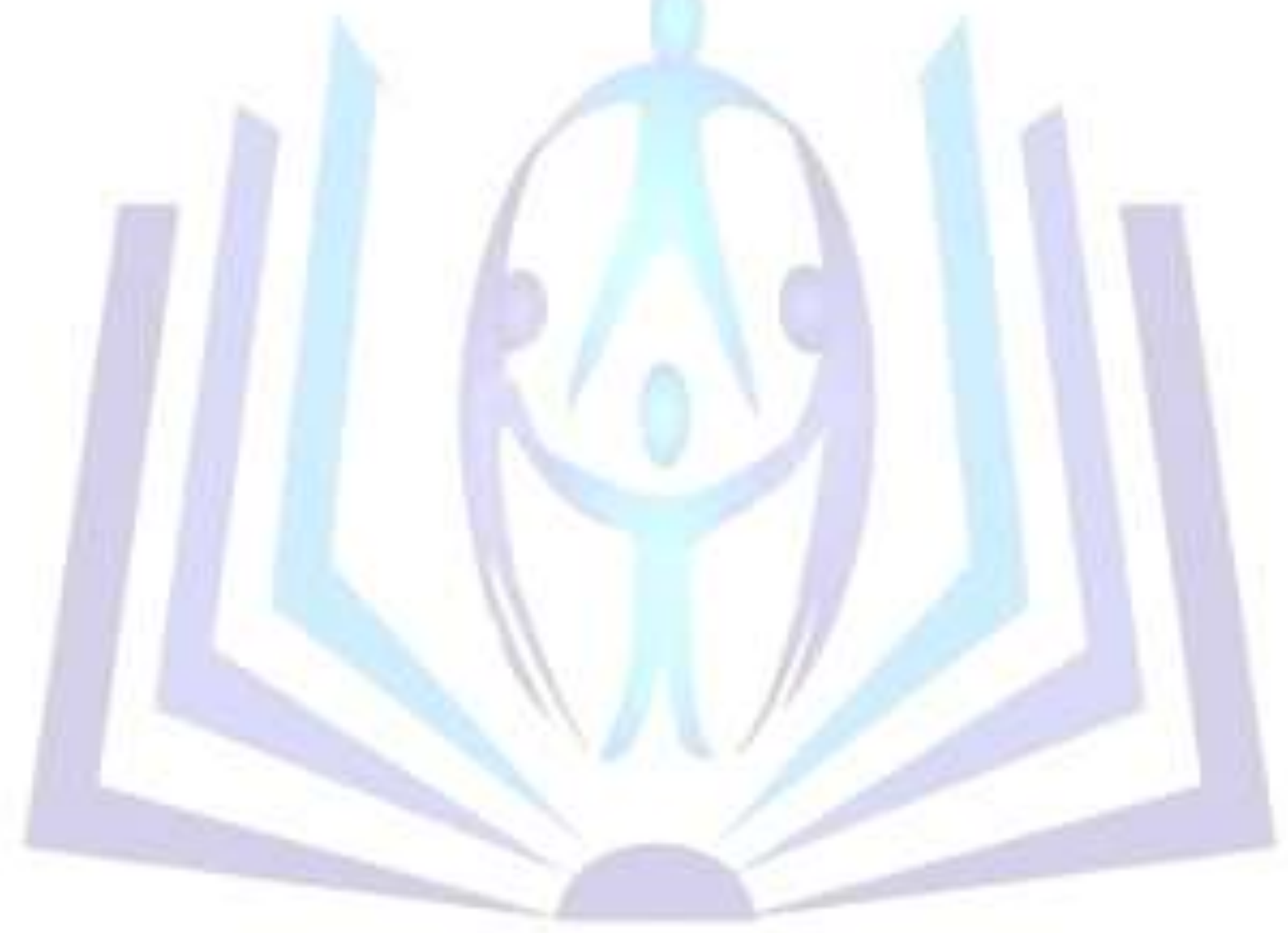

